Красящие вещества помещают в ступку между слоями неокрашенных веществ. Необходимо иметь отдельное рабочее место, и инвентарь.

Правило№10:

Порошки, в состав которых входят пахучие вещества с резким стойким запахом готовят так же на отдельном рабочем месте, используя необходимый для этого инвентарь.

Правило №11:

Жидкие ингредиенты добавляют в конце смешивания. Если они выписаны в большом количестве, то приготовление ведут в теплой ступке.

\title{
Правило №12:
}

Если используют сухой экстракт, то порошки готовят по общим правилам. Густые экстракты отвешивают на старированном кружке фильтровальной бумаги и переносят на головку пестика.

\section{Правило№13:}

Те лекарственные вещества, которые при порошковании образуют ядовитые пары, раздражающие слизистые оболочки измельчают в присутствии вспомогательной жидкости.

Упаковку и оформление делают в соответствии с физико-химическими свойствами. Используют разные сорта бумаги: проклеенная, вощенная, парафинированная, а также пергамент и целлофан.

$$
* * *
$$

1. https://pharmacopoeia.ru/ofs-1-4-1-0010-15-poroshki/

2. https://farmmedik.ru/poroshki-harakteristika-lf-klassifikatsiya-chastnaya-tehnologiya-prigotovleniyaporoshkov/

3. http://www.pharmspravka.ru/farmatsevticheskie-vorosyi-i-otvetyi/study/aptechnaya-texnologiya-lekarstvporoshki-v-aptechnom-proizvodstve.html

\section{Ермолина Т.А., Гильманов М.М. \\ Анализ состояния здоровья студентов в условиях европейского севера}

Северный (Арктический) федеральный университет имени М.В. Ломоносова (Россия, Архангельск)

doi: $10.18411 / 1 j-10-2020-26$

idsp: ljournal-10-2020-26

\section{Аннотация}

В статье представлены результаты анализа состояния здоровья студентов, проживающих в условиях Европейского Севера, выполнена оценка основных показателей здоровья.

Ключевые слова: медицинская активность, здоровье студентов.

Введение. Развитие большинства заболеваний так или иначе связано с факторами окружающей среды, «набор» которых для Европейского Севера России хорошо известен. Это низкая температура среды, фотопериодичность, высокая ионизация воздуха и резкие непериодические колебания напряжения геомагнитного и статического электрического поля, перепады атмосферного давления, низкая парциальная плотность кислорода в воздухе и др. Их неблагоприятное воздействие на организм может привести к развитию сдвигов в основных физиологических системах организма и формированию патологии у человека.Результатом длительного проживания на Севере является повышенное психоэмоциональное напряжение и тревожность, нарушение сна, лабильность настроения, неврозы, вегетативные 
полинейропатии, что наряду с наличием социально-экономических проблем приводит к высокой алкоголизации населения со всеми вытекающими отсюда последствиями [1].

Охрана и укрепление здоровья студенчества в основном определяется образом жизни. Повышенное внимание к нему проявляется на уровне общественного сознания, в сфере культуры, образования, воспитания. Образ жизни студента есть не что иное, как определенный способ интеграции его потребностей и соответствующей им деятельности, сопровождающих ее переживаний. Структура образа жизни выражается в тех отношениях субординации и координации, в которых находятся разные виды жизнедеятельности. Это проявляется в той доли бюджета времени личности, которая на них тратится, в том, на какие виды жизнедеятельности личность расходует свое свободное время, каким видам отдает предпочтение в ситуациях, когда возможен выбор. Если образ жизни не содержит творческих видов жизнедеятельности, то его уровень снижается. Одни студенты больше используют свободное время для чтения, другие - для занятий физическими упражнениями, третьи - на общение. Сознательно планируя затраты времени и усилий, студент может либо включаться в широкую сеть таких связей, либо обособляться.

Образ жизни студенту нельзя навязать извне. Личность имеет реальную возможность выбора значимых для нее форм жизнедеятельности, типов поведения. Обладая определенной автономностью и ценностью, каждая личность формирует свой образ действий и мышления. Личность способна оказывать влияние на содержание и характер образа жизни группы, коллектива, в которых она находится.

Выражением саморегуляции личности в жизнедеятельности является ее стиль жизни. Это поведенческая система, характеризующаяся определенным постоянством составляющих ее компонентов и включающая приемы поведения, обеспечивающие достижение студентом намеченных целей с наименьшими физическими, психическими и энергетическими затратами. Становясь привычкой, стиль жизни приобретает некоторую свободу от сферы сознательного контроля. Но для сферы самоуправления личности могут быть характерны и целенаправленные волевые акты самовоздействия. Этот уровень саморегуляции становится возможен при развитости иерархии мотивов личности, наличии мотиваций высокого уровня, связанного с общей направленностью интересов и ценностных ориентации, обобщенных социальных установок $[2,3,4,5]$.

Результаты. Для того чтобы выяснить медицинскую активность студентов, была поставлена задача провести опросу возрастной группы 19-23 года. Опрос проводился посредством анкетирования в социальных сетях. В опросе приняли участие 56 студентов, проживающих на Европейском Севере России. Процентное соотношение мужчин и женщин составило $51,9 \%$ и 48,1 \% соответственно. Средний индекс массы тела (ИМТ) у женщин составил 20,5, у мужчин - 21,5, что соответствует норме.

Состояние здоровья студенты оценили следующим образом: плохое - 3,7 \%; удовлетворительное - $63,0 \%$; хорошее - 22,2 \%; отличное $-11,1 \%$.

По мнению респондентов, негативно сказываются на здоровье следующие показатели: вредные привычки, стрессовые ситуации и неправильное питание. Частота заболеваний у 66,7 \% опрошенных 2-3 раза в год, что соответствует относительной норме. Снижение эмоционального напряжения происходит при курении у $23 \%$ опрошенных, употреблении алкоголя - у $21 \%$, выброса негатива на окружающих - у 17 $\%$, пассивного отдыха - у $28 \%$ и только $11 \%$ респондентов выбирают активные методы (занятие спортом, прогулки и т. д.). 84 \% студентов пропускают утренний прием пищи, который является наиболее значимым приемом пищи. Повышенная работоспособность для48 \% опрошенных проявляется вечером, для $23 \%$ - в ночные часы, для $20 \%$ - днем, для $9 \%$ - утром. Также заметна тенденция нарушения сна у студентов. Физиологическая норма сна в количестве часов у возрастной группы 19-22 
года - 7,5-8 часов. Было выявлено, что 74 \% учащихся спят 5-6 часов, $11 \%$ - 2-4 часа, $15 \%$ - 7-8 часов. Для студентов средний уровень медицинской активности у 51,9\%, низкий - у 37,0 \%, высокий - у 11,1\%.

Выводы. Таким образом, состояние своего здоровья студенты оценили на «удовлетворительно» в 63,0 \% случаев, уровень медицинской активности средний у 51,9 \%. Практические занятия по физическому воспитанию в вузе не гарантируют автоматически сохранение и укрепление здоровья студентов. Его обеспечивают многие составляющие образа жизни, среди которых большое место принадлежит регулярным занятиям физическими упражнениями, спортом, а также оздоровительным факторам.

$$
* * *
$$

1. Антропова М.В., Манке Г.Г., Бородкина Г.В. Факторы риска и состоя-ние здоровья учащихся // Здравоохранение Российской Федерации. - 2008. - № 3. - С. 29-3

2. Байер К. Здоровый образ жизни / К. Байер, Л. Шейнберг. - М.: Мир, 2016.- 368 с.

3. Козлова В. Рациональная пирамида / В. Козлова // Будь здоров. - 2010. -№ 8. - С. 5-10.

4. Здоровье [Электронный ресурс] // Здоровый образ жизни, ЗОЖ. - Ре-жим доступа: http://www.zdorovajaplaneta.ru/zdorovyj-obraz-zhizni-zozh/.

5. Образ жизни студентов [Электронный ресурс] // Здоровый образ жизни, ЗОЖ. - Режим доступа: https://studfile.net/preview/1724173/page:16/.

\section{Ермолина Т.А., Силантьева И.А. Анализ состояния здоровья жителей европейского севера}

Северный (Арктический) федеральный университет имени М.В. Ломоносова (Россия, Архангельск)

doi: $10.18411 / \mathrm{j}-10-2020-27$

idsp: ljournal-10-2020-27

\section{Аннотация}

В статье представлены результаты анализа состояния здоровьяжителей Европейского Севера, выполнена оценка основных показателей здоровья.

Ключевые слова: медицинская активность, хронические заболевания, здоровье.

Введение. В современных условиях жизни здоровье организма зависит от многих факторов, таких как экология, правильное питание, здоровый образ жизни и многое другое.

Проблема здоровья - одна из самых актуальных тем на сегодняшний день в связи с трудностями социально-экологического характера, которые переживает Россия в настоящее время $[1,2,3,4]$.

Для населения, проживающего на Севере, характерен биологический феномен хроническое полярное напряжение, которое снижает так называемые приспособительные резервы организма человека, уже в молодости вызывает многочисленные болезни, а затем преждевременное старение [5].

Результаты. Было проведено социологическое исследование состояния здоровья работников САФУ в возрасте от 31 года. Целью исследования являлось выяснение влияния образа жизни людей на их здоровье, отношение к своему здоровью и наличие факторов риска утраты здоровья. При изучении анкет были использованы пакеты прикладных статистических программ «Statistica» и электронные таблицы Microsoft Excel-2007.

По результатам исследования было выявлено следующее:

В опросе приняли участие 52 жителя Европейского Севера России. Процентное соотношение мужчин и женщин составило $38 \%$ и $62 \%$ соответственно. 